\author{
Jan BRODA ${ }^{1}$, Ewa PACZKOWSKA² \\ 1 University of Bielsko-Biala, Department of Materials Engineering, Willowa 2, 43-309 Bielsko-Biała, \\ Poland \\ ${ }^{2}$ Graduate of the University of Bielsko-Biala, Poland \\ ORCID / e-mail: \\ 1 0000-0003-2177-5705 / jbroda@ath.bielsko.pl
}

\title{
Surface morphology and physical properties of sheep wool of selected Polish breeds
}

Keywords:

sheep, Polish breed, wool, wool properties, surface morphology

\section{Morfologia powierzchni i właściwości fizyczne wełny owczej wybranych ras hodowanych w Polsce}

\section{Słowa kluczowe:}

owce, rasy polskie, wełna, właściwości wełny, morfologia powierzchni

\begin{abstract}
The wool of three Polish sheep breeds was investigated. Basic physical properties of fibres: length, diameter and strength were determined and surface morphology using scanning electron microscope were studied. It was stated that raw fibres are coated by significant quantity of a grease. After removing of the grease on the fibres surface fine scales are observed. For all three breeds the fibres are short and thick. The fibres length and thickness is characterized by significant diversity. The fibres exhibit low strength and high elasticity.
\end{abstract}

\begin{abstract}
Abstrakt
W ramach pracy przeprowadzono badania wełny trzech polskich ras owiec. W czasie badań zbadano morfologię powierzchni włókien oraz wyznaczono ich podstawowe parametry fizyczne: długość, średnicę i wytrzymałość. Badania morfologii powierzchni przeprowadzono dla włókien pranych i niepranych z zastosowaniem skaningowego mikroskopu elektronowego. W czasie badań stwierdzono, że włókna surowe pokryte są znaczną ilością tłuszczopotu. Po usunięciu tłuszczopotu na powierzchni włókien widoczne są dobrze zachowane łuski. Włókna wszystkich trzech ras są krótkie i grube, charakteryzują się dużym zróżnicowaniem długości i grubości, i posiadają niską wytrzymałość i dużą elastyczność.
\end{abstract}




\section{INTRODUCTION}

Sheep belong to animals, which were ones to be firstly domesticated by humans. Sheep husbandry was developed firstly in the Mesopotamia and later in other ancient great civilizations. In western Europe, sheep were known already in 6000 BCE. The sheep husbandry spread quickly in whole Europe and relatively quickly reached a Polish territory. The earliest records of sheep husbandry in Poland are dated back to 13th century. At the beginning of 19th century the sheep population was over 12 million. During the period between world wars in 20th century successive loss in sheep number was observed. After the second world war in 1947, the sheep population dropped to 0.7 million. In the next years, the sheep number increased considerably again and achieved the highest level in the middle of 80-ties of 20th century. Later sheep population decreased dramatically from 5 million in 1986 to less than 1 million in 1994 [Martyniuk and Rzepecki 1995]. In the next years, a further significant decrease in the amount of sheep was observed i.e. in 2005 sheep population in Poland was only 0.3 million and at the end of 2011 decreased to 0.21 million [Czaplicki and Ruszkowski 2007] (Fig. 1). Since then, the number of sheep is kept at this level [Niżnikowski and Strzelec 2012, Eurostat].

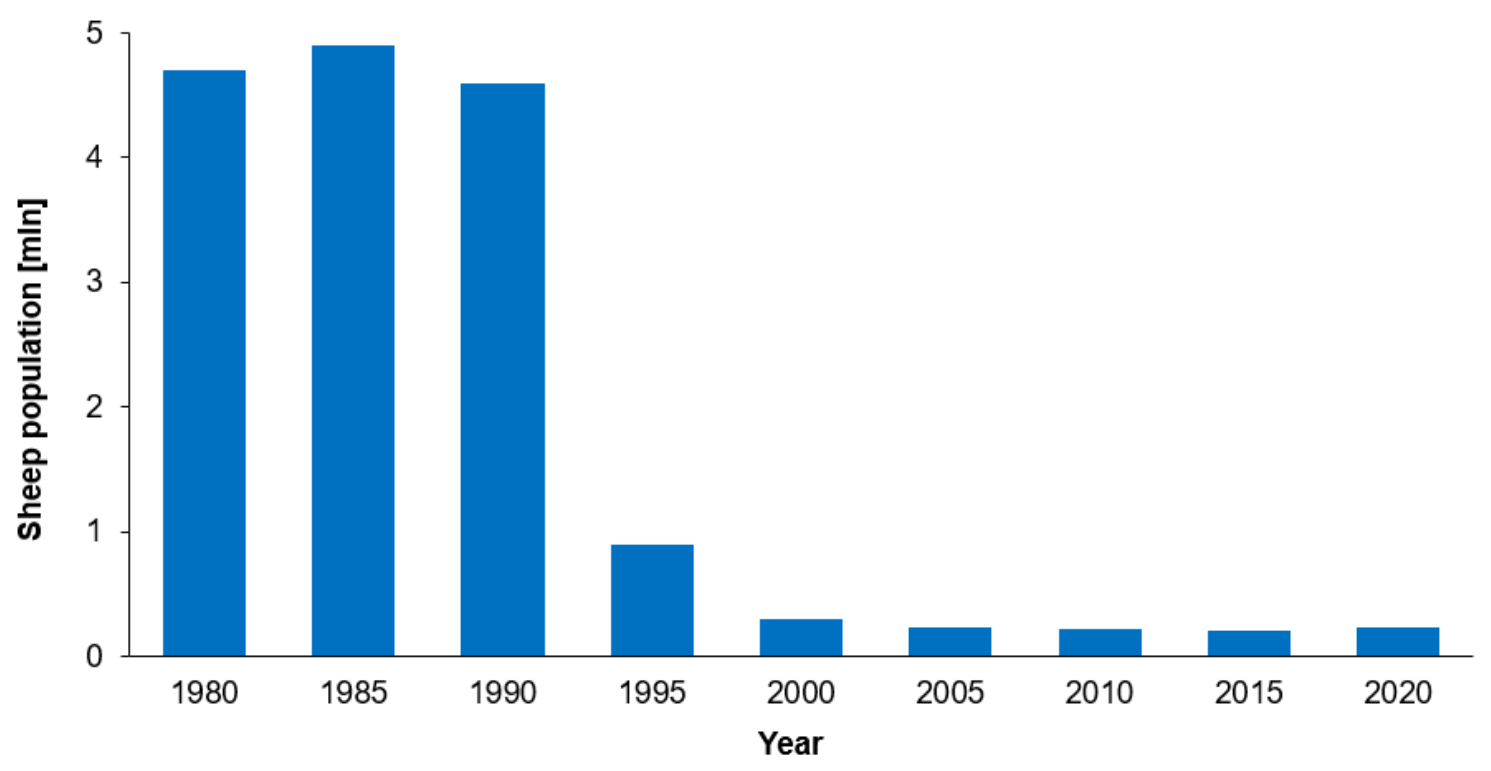

Fig. 1. Sheep population in Poland in years 1980-2020.

A large drop in the sheep population was caused by social and economic transformations, which led to the breakdown in agricultural production and the collapse of sheep husbandry. Before transformation sheep breeding was oriented on wool production. After the transformation, the previous program promoted the production of wool for the national market was finished. Removing the subsidies for wool and the introduction of the free market economy led to the reduction of the competitiveness of Polish wool. The sheep husbandry oriented on wool production became unprofitable and wool became a secondary and troublesome product of sheep husbandry [Ruszkowski and Czaplicki 2007]. The sheep farms reoriented their profile and focused more on the production of meat. The production of lamb's meat sold mainly to western European countries became the main source of the sheep breeders income [Rokicki 2009].

The Polish social transitions at the end of 20th century coincided with the drastic reduction in the demand for wool on the world market. The textile industry ceased to be inter- 
ested in low-quality domestic wool and preferred to proceed the fine merino wool transported from the other end of the world. As a result in almost the whole Europe, the wool obtained from local breeds lost drastically economic value, so the costs of sheep shearing outweighed the wool price. In many countries wool has been treated as a troublesome waste of sheep breeding, which was often buried on the field, stored without being scoured or deposed in local, not always legal, landfills.

In this situation in recent years, several ideas of processing local wool with various unconventional techniques or using it in unusual way have been examined. For this purpose, several studies on using wool products in civil engineering as soil reinforcement and erosion protection [Hejazi et al. 2012, Broda et al. 2018, 2020], in agriculture as fertilizers [Zheljazkov et al. 2009, Zoccola et al. 2015, Abdallah et al. 2019, Broda and Gawłowski 2020] as well in the construction industry as thermal and acoustic insulating materials [Corscaden et al. 2014, Broda and Bączek 2020] were performed. Moreover, a few research projects on using local wool were implemented. In the frame of the project implemented by the Institute of Natural Fibres and Medicinal Plants in Poznań several commercial products made from wool of different Polish breeds were obtained. In the same time in the University of Bielsko-Biala the Polish-Norwegian project aiming rational utilization of wool from Polish mountain sheep was initiated [Project Woolume].

Application of wool is dependent on its characteristics, mainly on the thickness of the fibres. Wool quality has an impact on processing efficiency and determines possibility of its further use. The fine wool with a diameter below $25 \mathrm{~mm}$ can be used for the production of luxury garments. The medium wool with a thickness in the range $25-35 \mathrm{~mm}$ is suitable for manufacturing carpets, blankets and felts. The coarser wool with a diameter of more than $35 \mathrm{~mm}$ possesses the lowest economic value and can be applied only for the production of technical textiles [Johnson et al. 2003].

The best wool with fine diameters is obtained from merino sheep raised mainly in Australia and New Zealand. The wool of several breeds bred in Europe possesses higher thickness and lower quality. At the moment in Poland 29 various sheep breeds are raised. The most popular are [Piwczyński et al. 2013]: Polish Merino (11.4\%), Pomeranian Sheep (11.2\%), Polish Heath Sheep (Wrzosówka) (11\%) and Zackel Sheep (Cakiel Podhalański) $(7.7 \%)$. The information on the characteristics of wool obtained from sheep of the Polish breeds is incomplete. During the recent studies wool of four popular breeds reared in Poland was investigated [Kicińska-Jakubowska et al. 2021]. For the purpose of our studies wool of three other less popular Polish breeds was chosen. During the research the morphology of the fibres was studied and the basic wool parameters were determined. On the basis of the performed measurements the wool quality was evaluated.

\section{EXPERIMENTAL}

\subsection{Investigated sheep breeds}

In investigations wool of three sheep breeds: Black-headed, Olkuska and Romanov was examined.

Black-headed sheep is a specialized crossbreed originating from England, which was imported to Poland in the interwar period to improve the primitive Polish breeds. Rams of black-headed sheep reach weight $90-130 \mathrm{~kg}$, while ewes 65-90 kg. Sheep have good musculature, a very fast growth rate and high quality of lamb carcasses. Rams and ewes have mean size head, no horns and rigid hard stand-off ears. Head, ears, and legs are cov- 
ered with black hair, while the rest of the body is coated with short and white wool. The fibres possess rough grip and exhibit high elasticity. The annual growth of the fleece is about $9 \mathrm{~cm}$. The average performance of greasy wool is about $5 \mathrm{~kg}$ for ewes and $7 \mathrm{~kg}$ for rams [Szewczuk et al. 2011].

The Olkuska sheep is a native Polish breed created in the 30-ties of 20th century in Olkusz region. The breed was obtained by crossing the local primitive population of ewes with Pomeranian rams. The breed is characterized by a very high fertility. Rams achieve weight $75-95 \mathrm{~kg}$, while ewes $55-75 \mathrm{~kg}$. Sheep have large head, long ears and large body frame of milk type constitution. Males and females do not have horns. Sheep are coated by uniform and white coat. The fibres length achieves $15 \mathrm{~cm}$. The annual performance for ewes equals $3.5-4.5 \mathrm{~kg}$. With the collapse of the sheep breeding the population of Olkuska sheep dramatically decreased and the breed was threatened with extinction. In 90-ties Olkuska sheep was integrated into the national biodiversity conservation program. The breeding of sheep was subsidized and the breeding on traditional areas were restored. Simultaneously the breeding in other places was initiated. As the result the number of flocks increased from 5 in 1997 to 47 in 2010. In this period the mean annual increase in the number of ewes was 59 and at the end the population achieves 590 [Murawski 2011]. At the moment the breed is raised in eight Polish provinces and enjoys considerable and growing popularity among breeders.

Romanov sheep is a typical sheepskin breed originating from the Upper Volga region in Russia [Desvignes et al. 1971]. The breed was known already in 17th century. Sheep are adapted to the cold inland climate and local feeding. The average weight of a male is 55$80 \mathrm{~kg}$ and a female amounts to $40-50 \mathrm{~kg}$. Sheep have small and narrow head and relatively long limbs. The rams may have horns. Sheep are coated by a mixture of fine grey wool and black outer guard hair. Romanov wool possess characteristic lustre, is thick and very strong. The mean greasy fleece weight is around $4.5 \mathrm{~kg}$. In 90-ties the Romanov breed was selected in the national program aiming improving fertility of sheep. In years 1997-2010 the number of flocks risen from 1 to 2 . By the mean annual increase in the number of ewes 8.7 the sheep population slightly increased.

\subsection{Methods}

The wool samples were taken from sheep raised in the Experimental Station in Grodziec Śląski of the National Research Institute of Animal Production from Kraków (Poland). During the research surface morphology of greasy and scoured wool fibres was studied and their basic geometrical and mechanical parameters were determined. The physical characteristics of wool were determined by several measurements determined on full-length staples taken from random positions in the fleece shorn from the sheep. The morphology studies were performed for fibres sputtered with gold using scanning electron microscope JEOLJSM 5500 LV. On basis of microscopic studies scales frequency and high of scales were determined. The fibre thickness were measured using optical projection microscope according to the Polish standard PN-ISO 137:2000. Based on the measurements the average values and standard deviation (S.D.) of fibres diameter were calculated. The fibres length were measured by measurements of individual fibres according to the Polish standard PN-ISO 6989. The tenacity of individual fibres were determined according to Polish standard PN-P-04930-07:1993. For the measurements the tensile machine Instron 5544 was used. 


\section{RESULTS}

Fig. 2 presents SEM microphotographs of grease wool fibres just shorn off the sheep. It is clearly seen that the surface of fibres is coated by significant quantity of grease.

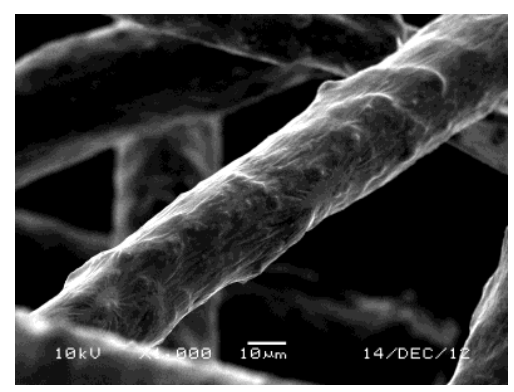

A

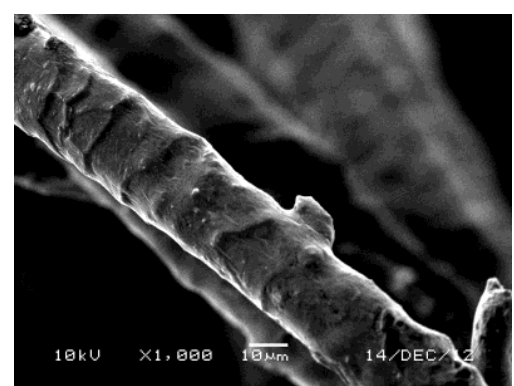

$B$

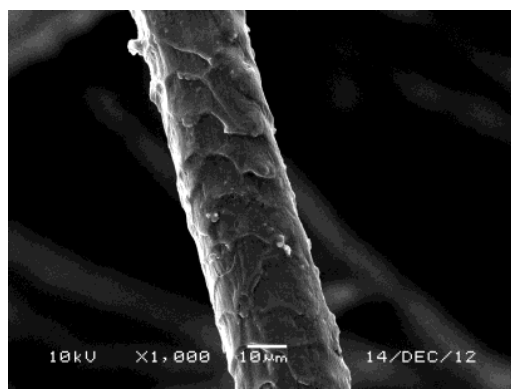

C

Fig. 2. SEM microphotographs of greasy wool: A) Black-headed; B) Olkuska; C) Romanov.

On Fig. 3 SEM microphotographs of scoured fibres are presented. On the fibres surface fine scales are well visible. The scales frequency and scales high calculated on the basis of microphotographs are presented in Tab. 1.

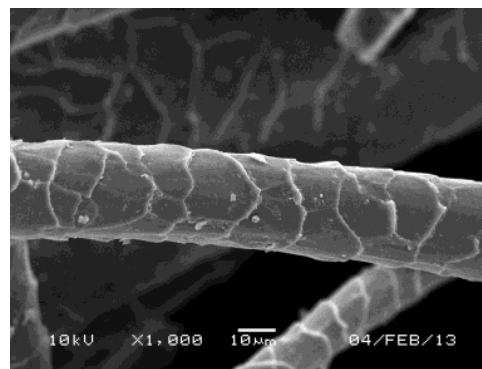

A

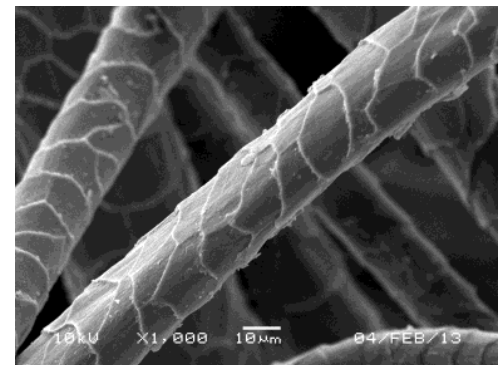

$B$

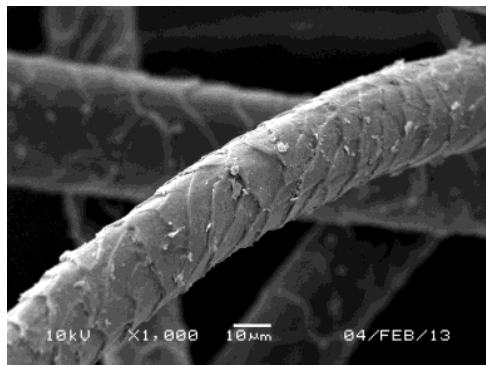

C

Fig. 3. SEM microphotographs of scoured wool: A) Black-headed; B) Olkuska; C) Romanov.

Table 1. Scales frequency and scales high of wool fibres.

\begin{tabular}{|c|c|c|}
\hline Sheep breed & Scales frequency $[1 / 100 \mu \mathrm{m}]$ & Average scales length $[\mu \mathrm{m}]$ \\
\hline Black-headed & 8 & 18 \\
\hline Olkuska & 8 & 17 \\
\hline Romanov & 14 & 8 \\
\hline
\end{tabular}

For the wool of the Black-headed and Olkuska sheep the scale frequency is low and the scales length is relatively high. For both breeds the scales frequency and scales dimensions are similar. For the wool of the Romanov sheep the dimensions of scales are much smaller and the scales frequency is much higher. Tab. 2 presents the measured values of the geometrical parameters of fibres: length and thickness. Additionally, the standard deviation of both parameters are shown. One can notice that all fibres are short and their length is remarkably lower than $100 \mathrm{~mm}$. The longest are the fibres of the Olkuska sheep. 
Tab. 2. Length and thickness of wool fibres.

\begin{tabular}{|c|c|c|}
\hline \multirow{2}{*}{ Sheep breed } & Length $[\mathrm{mm}]$ & Thickness $[\mu \mathrm{m}]$ \\
\cline { 2 - 3 } & Average \pm S.D. & Average \pm S.D. \\
\hline Black-headed & $41 \pm 11$ & $52.5 \pm 14.1$ \\
\hline Olkuska & $71 \pm 28$ & $44.4 \pm 13.3$ \\
\hline Romanov & $41 \pm 10$ & $50.8 \pm 13.9$ \\
\hline
\end{tabular}

All fibres are thick and their diameter exceeds $40 \mu \mathrm{m}$. The highest mean thickness $(52.5 \mu \mathrm{m})$ exhibit fibres of the Black-headed sheep. For this breed the distribution of fibres thickness is relatively narrow (Fig. 4). For other two breeds the distribution of fibres thickness is asymmetric and much wider. For the Romanov sheep in the fleece there is a high number of coarse fibres.
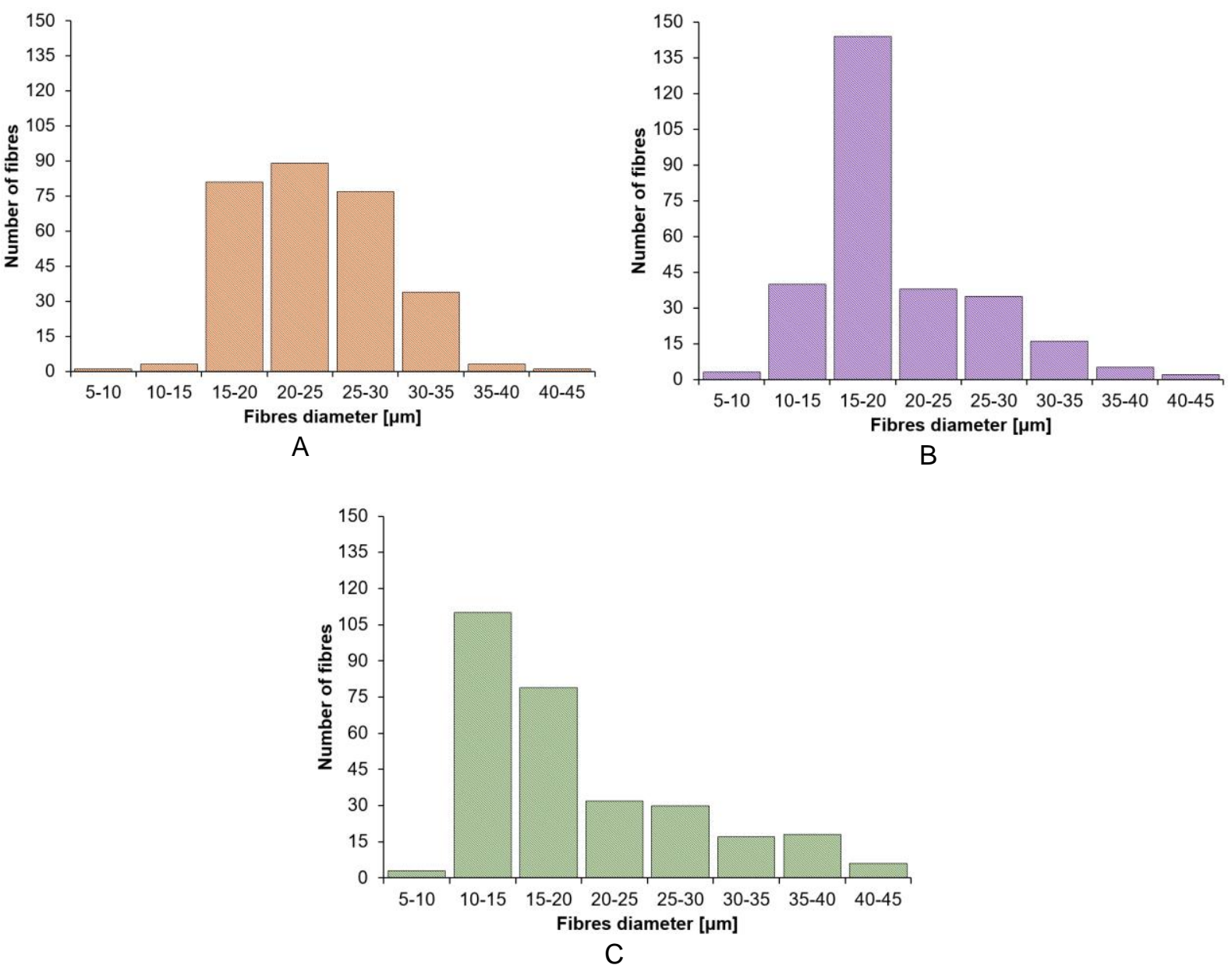

Fig. 4. The distribution of the fibres thickness: A) Black-headed; B) Olkuska; C) Romanov.

In Tab. 3 the basic mechanical parameters of fibres: breaking force and elongation at break are presented. The highest mean strength is revealed for the wool of the Black-headed sheep. For the Olkuska sheep the breaking force is lower. The lowest values were obtained for the wool from the Romanov sheep. The highest elongation at break is for the Olkuska sheep. 
Tab. 3. Mechanical parameters of wool fibres.

\begin{tabular}{|c|c|c|}
\hline \multirow{2}{*}{ Sheep breed } & Breaking force [cN] & Elongation at break [\%] \\
\cline { 2 - 3 } & Average \pm S.D. & Average \pm S.D. \\
\hline Black-headed & $22.6 \pm 6.5$ & $32 \pm 10.8$ \\
\hline Olkuska & $13.1 \pm 8.3$ & $52 \pm 19.8$ \\
\hline Romanov & $9.6 \pm 3.6$ & $46 \pm 16.2$ \\
\hline
\end{tabular}

\section{CONCLUSIONS}

1. The wool fibres obtained from all investigated breeds reveal poor quality.

2. For all three breeds fibres are short and thick. The fibres length and thickness is characterised by significant diversity.

3. The fibres exhibit low strength and high elasticity.

4. Due to the low quality the wool obtained from the studied breeds is not suitable for the production of highly qualified garments.

\section{REFERENCES}

Abdallah A., Ugolini F., Baronti S., Maienza A., Ungaro F., Camilli F. 2019. Assessment of two sheep wool residues from textile industry as organic fertiliser in sunflower and maize cultivation. Journal of Soil Science and Plant Nutrition, 19, 793-807.

Broda J., Bączek M. 2020. Acoustic properties of multi-layer wool nonwoven structures. Journal of Natural Fibres, 17, 1567-1581.

Broda J., Gawłowski A. 2020. Influence of sheep wool on slope greening. Journal of Natural Fibres, $17,820-832$.

Broda J., Gawłowski A., Przybyło S., Biniaś D., Rom M., Grzybowska-Pietras J., Laszczak R. 2018. Innovative wool geotextiles designed for erosion protection. Journal of Industrial Textiles, 48, 599-611.

Broda J., Mitka A., Gawłowski A. 2020. Greening of road slope reinforced with wool fibres. Materials Today: Proceedings, 31, S2, 280-285.

Corscadden K., Biggs J., Stiles D. 2014. Sheep's wool insulation: A sustainable alternative use for a renewable resource? Resources, Conservation and Recycling, 86, 9-15.

Czaplicki Z., Ruszkowski K. 2007. Sheep farming in Poland - collapse or temporary setback. Przegląd Włókienniczy, 61, 11, 33-35.

Desvignes A., Boutler N., Boyajean D., Zuzine N. 1971. La race ovine Romanov. Annales de Zootechnie, INRA/EDP Sciences, 20(3), 353-370.

Eurostat: http://appsso.eurostat.ec.europa.eu/nui/show.do?dataset=apro_mt_Issheep\&lang=en.

Johnson N., Wood E., Ingham P., McNeil S., McFarlane I. 2003. Wool as a technical fibre. TheJournal of the Textile Institute, 94(3), 26-41.

Hejazi S.M., Sheikhzadeh M., Abtahi S.M., Zadhoush A. 2012. A simple review of soil reinforcement by using natural and synthetic fibres. Construction and Building Materials, 30, 100-116.

Kicińska-Jakubowska A., Morales Villavicencio A., Zimniewska M., Przybylska P., Kwiatkowska E. 2021. Evaluation of wool quality parameters of Polish sheep breeds. Journal of Natural Fibres, on-line first, DOI: 10.1080/15440478.2021.1902895.

Martyniuk E., Rzepecki R. 1995. Sheep husbandry in Poland - an outline. [In:] Strategies for sheep and goat breeding (Ed. D. Gabina). CIHEAM, Zaragoza, 121-131.

Murawski M. 2011. Historia hodowli plennej owcy olkuskiej. Wiadomości Zootechniczne, 49(1), 15-20.

Niżnikowski R., Strzelec E. 2012. Sheep and wool production in Central and Eastern Europe. The $63^{\text {rd }}$ EAAP Annual Meeting, Book of Abstracts, Bratislava, 372-372.

Piwczyński D., Czajkowska A., Zalewska A. 2013. Zmiany cech reprodukcyjnych wybranych ras plennych owiec w Polsce w latach 1997-2010. Przegląd Hodowlany, 2, 20-22.

Project Woolume: http://woolume.ath.eu. 
Rokicki T. 2009. Przemiany w gospodarstwach owczarskich w Polsce. Roczniki Nauk Rolniczych, Seria G, 96, 3, 265-272.

Ruszkowski K., Czaplicki Z. 2007. Properties of national wool raw materials. Przegląd Włókienniczy, $61,12,39-41$.

Szewczuk M., Lachowski W., Żurawski G., Chociłowicz E., Czerniawska-Piątkowska E. 2011. Level of reproduction traits of ewes in blackhead sheep and growth of their offspring. Acta Scientiarum Polonorum Zootechnica, 10(2), 89-98.

Zheljazkov V., Stratton G., Pincock J., Butler S., Jeliazkova E., Nedkov N., Gerard P. 2009. Woolwasteas organic nutrient source for container-grown plants. Waste Management, 29, 2160-2164.

Zoccola M., Montarsolo A., Mossotti R., Patrucco A., Tonin C. 2015. Green hydrolysis as an emerging technology to turn wool waste into organic nitrogen fertiliser. Waste and Biomass Valorization, 6, 891-897. 